\title{
Effect of the presence of male and female flockmates on reproductive activity in ewes
}

\author{
D. O'Callaghan ${ }^{1}$, A. Donovan ${ }^{1}$, S. J. Sunderland ${ }^{1}$, M. P. Boland ${ }^{2}$ \\ and J. F. Roche ${ }^{2}$ \\ ${ }^{1}$ Faculty of Veterinary Medicine, and ${ }^{2}$ Faculty of Agriculture, University College Dublin, \\ Dublin 4, Ireland
}

\begin{abstract}
Four experiments were carried out to determine the effect of the presence of ewes and rams on the reproductive state of ewes. In Expt 1, the breeding season of ewes kept with a vasectomized ram ended later (April $18 \pm 8$ days; mean \pm SEM) than that of ewes isolated from rams ( 6 March \pm 7 days; $P<0.01$ ). In Expt 2, the end of the breeding season was later (5 May \pm 6 days; $P<0.05$ ) and the onset of the next breeding season earlier (29 September \pm 2 days; $P<0.001$ ) in ewes maintained with rams, compared with ewes isolated from rams ( 14 April \pm 7 days and 1 November \pm 2 days, respectively). There was no difference in the timing of, or variation in, reproductive transitions between ewes maintained either as individuals or in groups. In Expt 3, all ewes exposed to artificial short days from the date of the winter solstice and interrupted with 35 long days in spring resumed cyclicity (median date, 7 September; range, 59 days). Most ewes (seven of nine) exposed to short days from the date of the winter solstice and isolated from other ewes did not resume cyclicity in the following 11 months. In contrast, all ewes resumed cyclicity (median date, 19 October; range, 144 days) when exposed to short days but housed in social contact with other ewes that became reproductively active in early September; however, the onset of cyclicity was later than in ewes exposed to long days $(P<0.01)$. In Expt 4 , the number of LH pulses per $6 \mathrm{~h}$ in ewes exposed to rams was higher $(P<0.001)$ and the time of first ovulation earlier ( 16 August \pm 5 days; $P<0.05$ ) than it was in ewes that were isolated from rams and exposed to either oestrous or anoestrous ewes. We conclude that there was a chronic stimulus from rams to ewes that increased the duration of the breeding season and decreased anoestrus. There was no acute effect of introduction of oestrous ewes to anoestrous ewes on LH pulse frequency and time of first ovulation of the breeding season under the natural photoperiod, and the onset of the breeding season of housed anoestrous ewes exposed to a constant photoperiod was advanced by housing them with cyclic ewes. These results highlight a role for social or other animal-related stimuli in seasonal reproduction in ewes.
\end{abstract}

\section{Introduction}

Social communication between males and females can influence the reproductive state (for example in sheep, Underwood et al., 1944; pigs, Brooks and Cole, 1970; rodents, Vandenbergh, 1976 and cattle, Izard and Vandenbergh, 1982). Exposure of ewes in late anoestrus to a ram normally results in a rapid increase in LH pulse frequency (Martin et al., 1980) and ovulation approximately $40 \mathrm{~h}$ later (Oldham et al., 1979). The effect of rams on the reproductive system of ewes is thought to be mediated by pheromones present in the wool and wax from the fleece of rams (Knight and Lynch, 1980). Although direct physical contact with rams is not necessary for induction of a reproductive response (Watson and Radford, 1960), full physical contact is required to maximize the reproductive response of a ewe to a stimulus from a ram (Pearce and Oldham, 1988).

Although most studies investigating social communication between sheep have dealt with the influence of the ram on ovarian function in ewes, timing of the breeding season can also be influenced by the presence of other ewes. When ewes that had an advanced breeding season following treatment with melatonin were maintained in physical contact with anoestrous ewes, onset of reproductive activity occurred earlier in these ewes than in isolated controls (Kennaway et al., 1987). In addition, less variability in the onset of the breeding season was reported when blinded ewes were exposed to sighted rams (Legan and Karsch, 1983) or when pinealectomized ewes were exposed to pineal-intact ewes and rams (Wayne et al., 1989). These data suggest that social stimuli from both male and 
female flockmates can play a role in modulating reproductive transitions in ewes. Such effects are particularly evident if the primary synchronizing cue for the breeding season, in this case photoperiod, is disrupted or abolished.

The annual cycle of changing photoperiod is also an important environmental variable that times seasonal reproductive activity in many seasonal breeders (Gwinner, 1981). Specifically, annual changes in photoperiod are hypothesized to synchronize an endogenous rhythm of reproduction in ewes, resulting in breeding activity during autumn, winter and early spring (Malpaux et al., 1989). The photoperiod that occurs after the winter solstice has little effect on the duration of the ongoing breeding season (Wayne et al., 1990). This finding suggests that there are seasonal changes in the importance of current photoperiodic signals in the regulation of reproductive transitions. It is possible that there are seasonal changes in the ability of social signals from flockmates to alter reproductive activity in ewes, or that the relative importance of different synchronizing signals changes throughout the year.

In this paper we present results from four experiments that were carried out to investigate the effects of the presence of male and female flockmates on seasonal reproductive activity in ewes. The objective of Expt 1 was to determine the importance of the presence of a ram from the date of the winter solstice on the timing of the end of the breeding season in ewes. The objective of Expt 2 was to determine whether the presence of ewes and rams could affect the timing of reproductive transitions and the duration of anoestrus in other ewes. The objective of Expt 3 was to determine whether the presence of cyclic ewes could influence the timing of reproductive transitions in other ewes when normal changes in photoperiod were prevented and animals were maintained indoors with unchanging photoperiod. The objective of Expt 4 was to investigate a potential mechanism by which cyclic ewes could affect the reproductive state of other ewes. Specifically, introduction of oestrous or anoestrous ewes to other anoestrous ewes was compared with the introduction of rams; LH pulse frequency and onset of the breeding season were determined.

\section{Materials and Methods}

\section{Animals and treatments}

Experiment 1. The importance of the continued presence of a ram on the end of the breeding season was determined by maintaining sexually mature cyclic Galway ewes at pasture with a vasectomized ram for 2 months. They were penned in barns on the date of the winter solstice. The ewes were randomly allocated to one of two treatments (1) presence of ram: ewes were maintained with a vasectomized FinnishLandrace (Finn) ram ( $n=8)$; and (2) absence of ram: ewes were maintained from the date of the winter solstice in isolation from rams $(n=7)$. The groups were accommodated in pens approximately $600 \mathrm{~m}$ apart until the onset of the following anoestrous season. They had access to an open yard and were maintained with a natural photoperiod $\left(53^{\circ} \mathrm{N}\right)$. They were fed hay plus supplementary concentrates to maintain body weight, and water was available ad libitum.
Experiment 2. Sexually mature cyclic Finn ewes, maintained with natural photoperiod, were used to establish whether the presence of ewes and rams could affect the timing of reproductive transitions and the duration of anoestrus in other ewes. On 20 November, they were moved from pasture and randomly allocated to one of four treatments: (1) individual ewes, each exposed to the continuous presence of individual rams $(n=10)$; (2) group of ewes, exposed to the continuous presence of one ram $(n=9)$; (3) individual ewes, each isolated from rams but maintained with an ovariectomized ewe as a companion $(n=10)$; and (4) group of ewes, isolated from rams $(n=10)$.

All rams were vasectomized Finn rams. The ewes that were maintained with rams (treatments $I$ and 2) were kept at least $600 \mathrm{~m}$ from ewes that were isolated from rams (treatments 3 and 4) in different barns. Ewes maintained as individual ewes (treatments 1 and 3) were kept with their appropriate companion in one of 20 pens $\left(2.5 \mathrm{~m}^{2}\right)$ with solid partitions at the rear and at both sides. Ewes maintained as individuals in isolation from a ram (treatment 3) had an ovariectomized ewe of a different breed (Galway) as a companion, because separation from other ewes is considered stressful (Kilgour and de Langen, 1970; Parrott, 1990), suggesting that isolation may have major effects on the timing of reproductive transitions. By eliminating gonadal steroid output following ovariectomy, the companion ewe was considered unlikely to influence the reproductive state of the experimental ewe. There was no visual or physical contact between animals in different pens. However, airspace was common to animals in each barn. Ewes maintained in isolation from rams were fed and handled on a daily basis before ewes maintained with rams, to prevent isolated ewes being exposed to the wax and other physical particles of rams that could be transmitted on clothing. Animals were fed as in Expt 1 . The experiment was terminated on 19 November, one year later.

Experiment 3. Sexually mature Galway ewes were moved to two light-controlled rooms on the date of the winter solstice to determine whether the presence of cyclic ewes could influence the timing of reproductive transitions when normal changes in photoperiod were eliminated by housing ewes indoors with an unchanging photoperiod. Photoperiodic changes were regulated by electronic timers that operated fluorescent bulbs producing about $350 \mathrm{~lx}$ of light intensity lateral to the head of the ewes. A dim red light producing $<2 \mathrm{~lx}$ remained on continuously to facilitate night-time inspection of animals. The ewes were exposed to the winter solstice photoperiod ( $8.5 \mathrm{~h}$ light: $15.5 \mathrm{~h}$ dark) from the date of the winter solstice. On 5 February, ewes were randomly allocated to one of three treatments: (1) ewes were maintained with winter solstice photoperiod $(n=9)$; (2) ewes were maintained as in treatment 1 but this was interrupted by 35 long days ( $18 \mathrm{~h}$ light: $6 \mathrm{~h}$ dark) beginning on 20 April $(n=10)$, and (3) ewes were maintained with winter solstice photoperiod, as in treatment 1 but isolated from all other groups $(n=9)$. Apart from the 35 days when ewes on treatment 2 were exposed to long days, ewes on treatment 1 and 2 were mixed and kept in two photochambers (four or five ewes from each treatment were kept in each photochamber). The ewes were fed as in Expt 1 and the experiment was terminated on 30 November. 
Experiment 4. Sexually mature anoestrous Suffolk cross ewes exposed to natural photoperiod were penned in a barn in mid-July to investigate a potential mechanism by which the presence of cyclic ewes could affect the reproductive state of other ewes. They were randomly allocated to one of four treatments: (1) control: ewes were isolated from other ewes and rams $(n=8)$; (2) rams introduced: two fertile rams were introduced ( $n=9$ ); (3) oestrous ewes introduced: nine oestrous cyclic ewes were introduced $(n=9)$; and (4) anoestrous ewes introduced: eight anoestrous ewes were introduced $(n=8)$. Ewes were housed by treatment; visual and physical contact between groups was prevented but the airspace was common. Animals were introduced to their respective groups on 1 August (day 0 ). Pen sizes were adjusted to allow equal space to ewes on the four treatments following introduction of the novel sheep. The two rams were fertile Suffolk rams. The novel oestrous cyclic ewes were of the Galway breed and were exhibiting regular oestrous cycles at the time of introduction. While the breeding season of Galway ewes does not normally occur until mid-September, onset of regular oestrous cycles was advanced in these ewes by exposure to controlled photoperiods from the previous winter solstice ( $\mathrm{O}^{\prime} \mathrm{Callaghan}$ ef al., 1992). Oestrus was synchronized in these ewes by administration of progestagen pessaries (Veramix: Upjohn Ltd, Crawley, Sussex) for 12 days with removal $48 \mathrm{~h}$ before introduction to experimental ewes. Behavioural oestrus was confirmed before introduction by monitoring interest in a ram in an adjacent pen. Physical contact between these oestrous ewes and the ram was prevented. The anoestrous ewes were selected from a group of Blackface mountain-Border Leicester cross ewes, a breed that normally begins their breeding season later than the Suffolk cross experimental ewes. Animals were fed hay, and water was available ad libitum until the experiment was ended following determination of the onset of the next breeding season (September).

\section{Measurement of reproductive activity}

Reproductive activity was assessed from concentrations of progesterone in serum of blood samples collected at 3-4-day intervals throughout each experiment. Blood samples were kept at room temperature for $1 \mathrm{~h}$ after collection and then overnight at $4^{\circ} \mathrm{C}$. They were then centrifuged at $700 \mathrm{~g}$ for $20 \mathrm{~min}$, serum harvested and stored at $-20^{\circ} \mathrm{C}$ until analysed for progesterone using the non-extraction radioimmunoassay method of Ronayne and Hynes (1990). The interassay coefficient of variation (CV) for three serum pools with mean values of $0.4,1.6$ and $3.4 \mathrm{ng} \mathrm{ml}^{-\mathrm{I}}$ was $12.4,11.6$ and $8.5 \%$, respectively. The intra-assay $\mathrm{CVs}$ for the same three serum pools were $7.5,4.9$ and $6.4 \%$, respectively. The sensitivity of the assay was $0.2 \mathrm{ng} \mathrm{ml}^{-1}$.

In Expt 4, blood samples for $\mathrm{LH}$ analyses were collected from ewes (at 12-min intervals for $6 \mathrm{~h} ; 7-9$ animals per treatment) on three occasions. These periods were selected to provide information on pretreatment pulse frequency (day -1 ; 'pre'), acute effect of animal introduction (day 0; 'acute') and chronic longer term effects of introduction (day 2; 'chronic'). Blood samples were collected and processed as previously described and analysed for LH using a modification of the assay of Niswender ef al. (1968), which has been validated for use in our laboratory (O'Callaghan et al., 1991). The inter-assay CVs for three serum pools with mean values of $0.3,1.6$ and $4.7 \mathrm{ng}$ $\mathrm{ml}^{-1}$ were $12.3,8.0$ and $8.5 \%$, respectively. The intra-assay CVs for the same three serum pools were $10.3,5.8$ and $4.7 \%$, respectively. The sensitivity of the assay was $0.2 \mathrm{ng} \mathrm{ml}^{-1}$.

\section{Statistical analysis}

The end of the breeding season was defined as the date on which the last progesterone value was above $0.5 \mathrm{ng} \mathrm{ml}^{-1}$ in a series of two or more consecutive samples above $0.5 \mathrm{ng} \mathrm{ml}^{-1}$, or one sample was above $1.0 \mathrm{ng} \mathrm{ml}^{-1}$, followed in each case by four or more consecutive samples below $0.5 \mathrm{ng} \mathrm{ml}^{-1}$. The onset of the breeding season was defined as the date of the first progesterone value above $0.5 \mathrm{ng} \mathrm{ml}^{-1}$ in a series of two or more consecutive samples above $0.5 \mathrm{ng} \mathrm{ml}^{-1}$, or one sample above $1.0 \mathrm{ng} \mathrm{ml}^{-1}$, following four or more consecutive samples below $0.5 \mathrm{ng} \mathrm{ml}-1$. These definitions were used to determine dates of transfer from one reproductive state to the next and the results were subjected to analysis of variance and Student's $t$ test (Expt 1, 2 and 4) or, where appropriate owing to the distribution of the results, Kruskal-Wallis and Mann-Whitney non-parametric tests (Expt 3).

In Expt 2, a two (presence or absence of ram) by two (individual ovary-intact ewes or groups) factorial plan was used. No interaction between treatments was identified; results are therefore presented for the main effects only. Variation in the timing of reproductive transitions for the two main effects was determined using an F-test for equal variance. In Expt 3, significant differences in the number of ewes on each treatment becoming reproductively active were determined using Chi-squared analysis. In Expt 4, the frequency of LH pulses was determined using the Pulsar algorithm (Merriam and Wachter, 1982). $G(n)$ values for peak determination were $G(1)=3.8$, $G(2)=2.6, G(3)=1.9, G(4)=1.5$ and $G(5)=1.2$. The depth criterion for splitting peaks was 2.7. Treatment differences in pulse frequency between the 'pre-' and 'acute' and 'pre' and 'chronic' periods of the experiment were determined using analysis of variance. All statistical tests were considered different at a significance level of $P<0.05$.

\section{Results}

\section{Effect of the presence of rams on reproductive transitions in ewes}

In Expt 1, the end of the breeding season was delayed by 43 days $(P<0.01)$ in Galway ewes kept in the presence of a ram compared with that of ewes isolated from rams (Table 1 ). In Expt 2, the time of cessation of the breeding season was 21 days later $(P<0.05)$ in ewes maintained in the presence of a ram (treatments 1 and 2) than in ewes isolated from rams (treatments 3 and 4; Table 1). The onset of the subsequent breeding season was advanced by 33 days $(P<0.001)$ in ewes exposed to rams compared with that of ewes isolated from rams (Table 1). Thus, the period of anoestrus was shorter $(P<0.0001)$ in ewes exposed to rams (147 \pm 7 days) than in ewes isolated from rams ( $201 \pm 7$ days). The end of the 
Table 1. Date (mean \pm SEM for ewes in Expts 1,2 and 4; median for ewes in Expt 3) of end of the breeding season and onset of the next breeding season of ewes in the presence of other ewes or rams

\begin{tabular}{|c|c|c|c|}
\hline Treatment groups & $n$ & End of breeding season & Onset of next breeding season \\
\hline \multicolumn{4}{|l|}{ Experiment I (Galway ewes) } \\
\hline Presence of $\mathrm{ram}^{*}$ & 8 & 18 April \pm 8 days ${ }^{\mathrm{b}}$ & - \\
\hline Absence of ram & 7 & 6 March \pm 7 days $^{a}$ & - \\
\hline \multicolumn{4}{|l|}{ Experiment 2 (Finnish Landrace ewes) } \\
\hline ( 1 and 2) Presence of ram* & 19 & 5 May \pm 6 days $^{c}$ & 29 September \pm 2 days $^{e}$ \\
\hline (3 and 4) Absence of ram & 20 & 14 April \pm 7 days $^{\mathrm{d}}$ & 1 November \pm 2 days $^{f}$ \\
\hline (1 and 3) Individual ovary-intact & 20 & 28 April \pm 8 days & 15 October \pm 4 days \\
\hline (2 and 4) Group ovary-intact & 19 & 22 April \pm 6 days & 17 October \pm 5 days \\
\hline \multicolumn{4}{|l|}{ Experiment 3 (Galway ewes) } \\
\hline (1) WSP group & 9 & - & 19 October $^{8}$ \\
\hline WSP plus $35 \mathrm{LD}$ & 10 & - & 7 September ${ }^{h}$ \\
\hline WSP-isolated & 9 & - & $\mathrm{N} / \mathrm{A}^{+}$ \\
\hline \multicolumn{4}{|l|}{ Experiment 4 (Suffolk cross ewes) } \\
\hline (1) Control & 8 & - & 9 September \pm 4 days $^{c}$ \\
\hline Introduce rams ${ }^{* *}$ & 9 & - & 16 August \pm 5 days ${ }^{d}$ \\
\hline Introduce oestrous ewes & 9 & - & 3 September \pm 7 days $^{c}$ \\
\hline Introduce anoestrous ewes & 8 & - & I September \pm 4 days $^{c}$ \\
\hline
\end{tabular}

*Vasectomized ram.

${ }^{* *}$ Fertile rams.

${ }^{+} \mathrm{N} / \mathrm{A}$, not applicable as only two of nine ewes ovulated.

${ }^{\mathrm{ab}} P<0.01,{ }^{\mathrm{cd}} P<0.05$, ${ }^{\text {ef }} P<0.001$ (Student's $t$ test), ${ }^{\mathrm{h}} \mathrm{P}<0.02$ (Mann-Whitney $\mathrm{U}$ test) within experiment.

LD: long days; WSP: winter solstice photoperiod ( $8.5 \mathrm{~h}$ light:15.5 h dark).

breeding season or the onset of the subsequent breeding season was not more variable in ovary-intact ewes isolated from or exposed to rams $(P>0.05)$.

\section{Effect of presence of ewes on the reproductive transitions in other} ewes

In Expt 2, there was no difference in the timing of reproductive transitions between ovary-intact ewes maintained alone (treatments $I$ and 3 ) and those in a group (treatment 2 and $4 ; \quad P>0.05$ ). Duration of anoestrus was similar ( $179 \pm 9$ days and $170 \pm 10$ days, respectively, for ewes exposed to or isolated from other ovary-intact ewes). Similarly, there was no difference in the variation in the timing of reproductive transitions in ovary-intact ewes whether maintained as individuals or as a group $(P>0.05)$.

In Expt 3, all ewes exposed to winter solstice photoperiod and interrupted with 35 long days in spring resumed ovulation in early September (Table 1; Fig. 1). In contrast, the onset of reproductive activity was delayed in ewes maintained in winter solstice photoperiod in isolation $(P<0.01)$, and only two of these nine ewes had ovulated before 30 November. One of these two ewes had regular reproductive cycles from 25 September, whereas the other had irregular cycles from 20 July. The reproductive response of ewes maintained in winter solstice photoperiod and in social contact with ewes exposed to 35 days of long-day photoperiod was different from that of ewes maintained in winter solstice photoperiod in isolation from other cyclic ewes. The number of ewes becoming reproductively active $(9$ of 9$)$ was greater $(P<0.01)$ and the

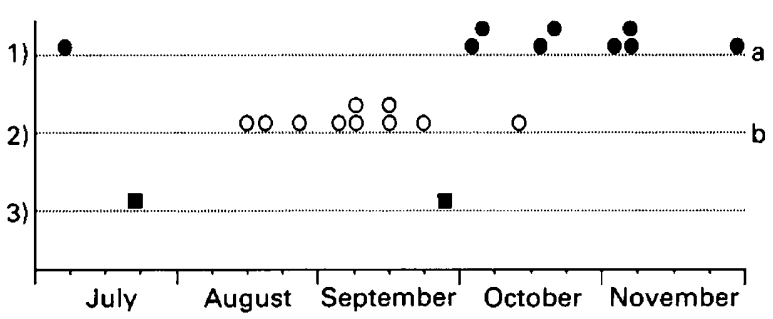

Fig. 1. Plot showing onset of ovulatory cycles for individual ewes in the three treatment groups in Expt 3: (1) ewes maintained with winter solstice photoperiod (WSP) ( $8.5 \mathrm{~h}$ light:15.5 h dark, O, $n=9$ ); (2) ewes maintained with winter solstice photoperiod that was interrupted with 35 long days from 20 April ( $18 \mathrm{~h}$ light: $6 \mathrm{~h}$ dark, $\bigcirc$, $n=10$ ) and (3) ewes maintained with winter solstice photoperiod that were isolated from other groups $(\boldsymbol{\square}, n=9)$. ab: results of treatments are significantly different $(P<0.01)$.

median time of onset of reproductive activity was advanced $(P<0.01)$ compared with that of ewes maintained on short days in isolation from all other ewes, but delayed when compared with that of ewes exposed to 35 long days (Table 1; $P<0.01$ ).

Effect of acute introduction of rams or ewes on reproductive activity in ewes

The number (mean \pm SEM) of LH pulses per $6 \mathrm{~h}$ was not different in the three time periods (day $-1,0,2$ ) for isolated control ewes, or for ewes exposed to oestrous or anoestrous 


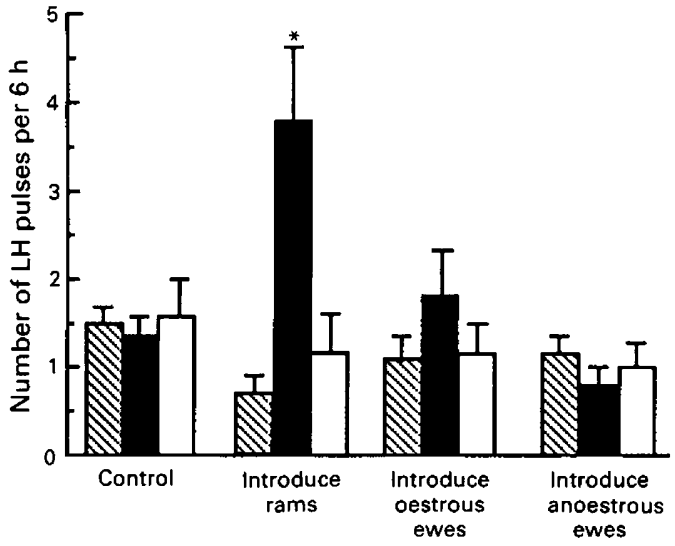

Fig. 2. Mean ( \pm SEM) number of LH pulses per $6 \mathrm{~h}$ in control anoestrous ewes and anoestrous ewes exposed to novel rams, oestrous ewes or anoestrous ewes (Expt 4). Results are presented for days -1 (団), 0 ( $\mathbf{D}$ ) and 2 (圆) relative to introduction of a novel animal. ${ }^{*} P<0.001$ versus days -1 and 2 within treatment.

ewes (Expt 4, Fig. 2). The differences in the number of $\mathrm{LH}$ pulses identified after introduction of novel sheep ('acute') compared with the pretreatment period were $-0.1 \pm 0.1$, $-0.4 \pm 0.3$ and $0.7 \pm 0.6 \mathrm{LH}$ pulses per $6 \mathrm{~h}$ for isolated control ewes or for ewes to which anoestrous ewes or cyclic ewes were introduced, respectively. However, the number of pulses per $6 \mathrm{~h}$ in the group to which rams were introduced was higher $(P<0.001)$ in the 'acute' period $(3.9 \pm 0.7)$ than in the pretreatment $(0.7 \pm 0.2)$ and the 'chronic' $(1.2 \pm 0.4)$ periods. Thus, the difference in the number of $\mathrm{LH}$ pulses identified in this group between the period when rams were introduced ('acute') and the pretreatment period was $3.2 \pm 0.6 \mathrm{LH}$ pulses per $6 \mathrm{~h}$. The time of first ovulation in the group of ewes with rams introduced was advanced by 24,18 or 16 days $(P<0.05)$ compared with that of control ewes, ewes to which oestrous ewes were introduced or ewes to which anoestrous ewes were introduced, respectively (Table 1).

\section{Discussion}

The results of these experiments demonstrate a chronic effect of the presence of a ram on the annual reproductive cycle of ewes. They also confirm previous observations that the ram can have an acute effect on LH pulse frequency and ovulation in ewes in late anoestrus, but introduction of novel oestrous ewes had no effect on LH pulse frequency and ovulation in anoestrous ewes. The results of Expt 1 indicate that the end of the breeding season can be delayed by over two ovulatory cycles by the continued presence of rams from the date of the winter solstice. Thus, the timing of seasonal reproductive transitions from the breeding season to anoestrus in natural conditions is not solely regulated by photoperiod. These results are similar to the effect of exposure to bucks on the ovulatory period of female goats (Restall, 1992). These effects of the ram on the end of the breeding season were evident at a time of year when normal changes in the photoperiod are hypothesized to be relatively unimportant in determining the time of change from the breeding season to the anoestrous state (Wayne et al., 1990). This finding suggests that there is more than one signal involved in synchronization of the breeding season in ewes and that the relative importance of these signals may change throughout the year. The results of Expt 2 extend the findings of Expt $I$ by demonstrating that the presence of a ram can also advance the onset of the subsequent breeding season by almost two ovulatory cycles, thereby markedly shortening the duration of anoestrus. These findings also provide evidence that the presence of a ram can affect reproductive transitions at more than one time of the year.

Results from Expt 2 also showed that the timing of reproductive transitions was not different in ovary-intact ewes maintained in a group or alone (no gonadal-intact pen mates). Experiments reporting effects of the presence of one ewe on the reproductive state of another normally use experimental models in which the photoperiod is disrupted by means of blinding (Legan and Karsch, 1983) or pinealectomy (Wayne et al., 1989). In those experiments, intact ewes and rams appeared to influence the timing of reproductive transitions in ewes devoid of normal photoperiodic cues. While significant effects of one ewe on the time of the breeding season of another ewe have been reported in animals subjected to the natural photoperiod (Kennaway et al., 1987), no significant effect on the timing of reproductive transitions was noted in this experiment.

As photoperiod is the primary synchronizer of the endogenous rhythm of reproduction and, in this case, it was not disrupted, this may help to explain the absence of an effect of maintaining ewes in groups on the timing of reproductive transitions. Alternatively, the lack of a difference in the time of reproductive transitions in ovary-intact ewes maintained individually in Expt 2 may be due to incomplete isolation used in this study. In the conditions of this experiment, isolation was only of a physical and visual nature. Airspace in each location was common and, therefore, the involvement of pheromonal or auditory communication cannot be ruled out. In the case of ram stimulation of anoestrous ewes, the smell and sound of rams has been found to be sufficient to provide some stimulating influence (Watson and Radford, 1960), albeit not as effective as in ewes that are in full visual and physical contact with rams. Geary and Reeves (1992) reported that bulls use visual observation of females as the primary indicator of oestrus and that olfaction alone provides insufficient stimuli to indicate a preference towards a specific heifer in oestrus or in dioestrus. Thus, it is likely that our experimental conditions were not limiting the manifestation of the animal to animal interactions.

The question of variation within treatments in the timing of reproductive transitions in ewes exposed to different environmental conditions was also addressed in Expt 2. No difference in variation in the timing of reproductive transitions was noted whether ewes were exposed to a ram or not. In addition, there was no difference in variation in the timing of reproductive transitions in ewes maintained in a group or as individuals. These results support the suggestion that there is a hierarchy of social signals involved in synchronization of the breeding season. The results suggest that the main synchronizing factor recognized by ewes, during a natural photoperiod at least, is photoperiodic and not pheromonal in origin. This result was surprising as, under certain conditions at least (acute ram introduction to anoestrous ewes), rapid physiological responses 
can occur resulting in synchronous ovulations over a short period. The lack of effect of one ewe on the timing of reproductive transitions in another may be due to the fact that natural photoperiodic changes are a much more powerful synchronizing cue than are social signals from one ewe to another. Alternatively, the time interval under the natural photoperiod from when the first ewe becomes cyclic until that ewe can affect other anoestrous ewes may be too long to allow identification of this effect.

The confounding effects of maintaining ewes with the natural photoperiod were excluded in Expt 3 by using an artificial photoperiod. In the case of ewes that had no access to increasing photoperiod signals from the date of the winter solstice and that were isolated from other cyclic ewes, the onset of the next breeding season was markedly delayed and more variable. In contrast, ewes with no access to increasing photoperiod signals but that were kept in physical contact with ewes induced to resume cyclicity by prior exposure to longday photoperiod had a relatively synchronous onset of reproductive activity in autumn. This suggests that social cues between one ewe and another can be a powerful synchronizing signal, at least in the absence of changing photoperiod in the spring. The second issue identified in Expt 3 was the long time lag ( 6 weeks) between exposure of an individual ewe maintained in winter solstice photoperiod to cyclic ewes and the expression of reproductive activity in that ewe. This interval is longer than the normal variation between ewes in resuming cyclicity under natural photoperiod conditions (Quirke et al., 1986). This time lag may explain why differences in the variation in timing of reproductive transitions were not seen in ewes subjected to the natural photoperiod.

The mechanisms by which continuous exposure to rams or ewes may influence the timing of reproductive transitions in ewes are not clear. In the case of ewes re-introduced to rams after a period of isolation, ovulation occurs within 2 days (Oldham et al., 1979). This finding is consistent with the suggestion of Underwood et al. (1944) that isolation of ewes from rams is a prerequisite for effective stimulation of ovulation by rams. In Expts 1 and 2, rams were present throughout the experiment and so the impact of the introduction of a ram did not arise. Thus, the effects of rams on the expression of the breeding season in these experiments are chronic effects of rams in contrast to the acute effect of introduction of a novel ram. It has also been reported that the continuous presence of a ram, as distinct from acute introduction, can influence the timing of ovulation (Hall et al,, 1986; Al Mauly et al., 1991). Similar effects have been reported in postpartum cows, in which the interval between calving and onset of ovulation was reduced in cows exposed to bulls (Zalesky et al., 1984; Custer et al., 1990).

Possible mechanisms by which the presence of one ewe could affect reproductive activity in others were examined in Expt 4. The results indicate that $\mathrm{LH}$ pulse frequency in ewes is not markedly altered following introduction of novel oestrous or anoestrous ewes. This experiment was carried out under natural photoperiod conditions; the effect on LH pulse frequency of introduction of cyclic ewes to anoestrous ewes kept in constant photoperiod may be different as the relative importance of photoperiod and presence of other flockmates may change in such circumstances. However, even in these conditions it is unlikely that rapid increases in LH pulse frequency occur, as ovulations in ewes in Expt 3 did not begin until 6 weeks after introduction of cyclic ewes. In contrast to the situation after ram introduction, the onset of the breeding season was not altered by exposure to cyclic or anoestrous ewes 1 month before the normal breeding season. As cyclic ewes were introduced to anoestrous ewes in Expt 4 less than 6 weeks before the normal onset of the breeding season, and given the time required for cyclic ewes to induce ovulations in anoestrous ewes in Expt 3, it is now evident that it is unlikely that the onset of the breeding season would have been altered in this group. It remains to be determined whether introduction of cyclic ewes to anoestrous ewes at an earlier time of the year can advance the breeding season.

In conclusion, the results from these experiments indicate that chronic stimuli from rams can play a major role in timing the end of the breeding season and the onset of the subsequent breeding season in ewes under natural photoperiod conditions. There was no effect of introduction of novel oestrous ewes to other anoestrous ewes in late summer on subsequent LH pulse frequency or time of ovulation in ewes under natural photoperiod. However, in housed ewes under controlled photoperiod, effects of oestrous ewes on flockmate anoestrous ewes were obtained, indicating that female-female social interactions can play a role in the timing of reproductive transitions in ewes.

The authors thank G. Claffey, P. Duffy, M. Fitzpatrick, F. Griffith, N. Hynes and S. Ni Ceallaigh for technical assistance, D. H. Williams for statistical analysis, and W. J. Enright, F. J. Karsch, S. M. Moenter, N. L. Wayne and C. J. I. Woodfill for help in the experimental designs. They also thank Clonatec Ltd, France, G. Niswender, NIDDK and the National Hormone and Pituitary Program for supplying assay reagents. This work was partly supported by BioResearch Ireland, the Irish Electricity Supply Board and Hoechst Ireland Ltd. Abstracts of these data were presented at the 1990 and 1991 annual conference of the Society for the Study of Fertility and the 1991 annual conference of the Society for the Study of Reproduction.

\section{References}

Al-Mauly NZN, Bryant MJ and Cunningham FJ (1991) Effect of the introduction of rams on the pulsatile release of luteinizing hormone and the onset of reproductive activity in ewe lambs Animal Production 53 209-214

Brooks PH and Cole DJA (1970) The effect of the presence of a boar on the attainment of puberty in gitts Journal of Reproduction and Fertility 23 435-440

Custer EE, Berardinelli JG, Short RE, Wehrman M and Adair R (1990) Postpartum interval to estrus and patterns of $\mathrm{LH}$ and progesterone in first-calf suckled beef cows exposed to mature bulls Journal of Animal Science 68 1370-1377

Geary TW and Reeves JJ (1992) Relative importance of vision and olfaction for detection of estrus by bulls journal of Animal Science 70 2726-2731

Gwinner E (1981) Annual rhythms: perspective. In Handbook of Behavioral Neurobiology Vol 4 pp 381-389 Ed. J Aschoff. Plenum Press, New York

Hall DG, Fogarty NM and Gilmore AR (1986) Seasonality of ovulation and estrus and the ram effect in poll Dorset ewes Theriogenology 25 455-461

lzard MK and Vandenbergh JG (1982) The effects of bull urine on puberty and calving date in crossbred beef heifers Journal of Animal Science 55 1160-1168

Kennaway DJ, Dunstan EA and Staples LD (1987) Photoperiodic control of the onset of breeding activity and fecundity in ewes Journal of Reproduction and Fertility Supplement 34 187-199

Kilgour $\mathbf{R}$ and de Langen $H$ (1970) Stress in sheep resulting from management practices Proceedings of the New Zealand Society for Animal Production 30 65-76

Knight TW and Lynch PR (1980) Source of ram pheromones that stimulate ovulation in the ewe Animal Reproduction Science 3 133-136 
Legan SJ and Karsch FJ (1983) Importance of retinal photoreceptors to the photoperiodic control of seasonal breeding in the ewe Biology of Reproduction $29316-325$

Malpaux B, Robinson JE, Wayne NL and Karsch FJ (1989) Regulation of the onset of the breeding season of the ewe: importance of long days and of an endogenous reproductive rhythm Journal of Endocrinology 122 269-278

Martin GB, Oldham CM and Lindsay DR (1980) Increased plasma LH levels in seasonally anovular Merino ewes following the introduction of rams Animal Reproduction Science 3 125-132

Merriam GR and Wachter KW (1982) Algorithms for the study of episodic hormone secretion American Journal of Physiology 243 E310-E318

Niswender GD, Midgley AR Jr and Reichert LE Jr (1968) Radioimmunologic studies with murine, bovine, ovine and porcine luteinizing hormone. In Gonadotropins pp 299-306 Ed. E Rosenberg. Geron-X, Los Altos

O'Callaghan D, Karsch FJ, Boland MP and Roche JF (1991) Role of short days in timing the onset and duration of reproductive activity in ewes under artificial photoperiods Biology of Reproduction 44 23-28

O'Callaghan D, Donovan A, Karsch FJ, Boland MP and Roche JF (1992) Reproductive response of ewes to a specific photoperiodic challenge at different times of the year. Proceedings of the Third Meeting of the Society for Research on Biological Rhythms Amelia Island, Florida, 1992 Abstract 68

Oldham CM, Martin GB and Knight TW (1979) Stimulation of seasonally anovular Merino ewes by rams. I Time from introduction of the rams to the preovulatory LH surge and ovulation Animal Reproduction Science 1 283-290

Parrott RF (1990) Physiological responses to isolation in sheep. In Social Stress in Domestic Animals pp 212-226 Eds R Zayan and R Dantzer. Kluwer Academic Publishers, Dordrecht

Pearce GP and Oldham CM (1988) Importance of non-olfactory ram stimuli in mediating ram-induced ovulation in the ewe Journal of Reproduction and Fertility 84 333-339
Quirke JF, Hanrahan JP, Loughnane W and Triggs R (1986) Components of the breeding and non-breeding seasons in sheep: breed effects and repeatability Irish Journal of Agricultural Research 25 167-172

Restall BJ (1992) Seasonal variation in reproductive activity in Australian goats Animal Reproduction Science 27 305-318

Ronayne E and Hynes N (1990) Measurement of plasma progesterone concentrations by extraction and non-extraction radioimmunoassays Irish Journal of Agricultural Research 29 109-115

Underwood EJ, Shier FL and Davenport N (1944) Studies in sheep husbandry in W.A. V The breeding season of Merino, Crossbred and British breed ewes in the agricultural districts Journal of Agriculture (Western Australia) 2 135-143

Vandenbergh JG (1976) Acceleration of sexual maturation in female rats by male stimulation Journal of Reproduction and Fertility 46 451-453

Watson RH and Radford HM (1960) The influence of rams on onset of oestrus in Merino ewes in the spring Australian Journal of Agricultural Research 11 65-71

Wayne NL, Malpaux B and Karsch FJ (1989) Social cues can play a role in timing onset of the breeding season of the ewe Joumal of Reproduction and Fertility 87 707-713

Wayne NL, Malpaux B and Karsch FJ (1990) Photoperiodic requirements for timing onset and duration of the breeding season of the ewe: synchronization of an endogenous rhythm of reproduction Journal of Comparative Physiology A166 835-842

Zalesky DD, Day ML, Garcia-Winder M, Imakawa K, Kittok RJ, D'Occhio MJ and Kinder JE (1984) Influence of exposure to bulls on resumption of estrous cycles following parturition in beef cows Journal of Animal Science $\mathbf{5 9}$ 1135-1139 